\title{
Immunoprophylaxis and Immunotherapy of Respiratory Syncytial Virus-Infected Mice with Respiratory Syncytial Virus-Specific Immune Serum
}

\author{
BARNEY S. GRAHAM, THEOPHILUS H. DAVIS', YI-WEI TANG, AND WILLIAM C. GRUBER \\ Departments of Medicine /B.S.G., T.H.D., Y.-W.T./ and Pediatrics /W.C.G.J. Vanderbilt University \\ School of Medicine. Nashville. Tennessee 37232
}

\begin{abstract}
The effects of passive respiratory syncytial virus (RSV) immune serum given as preinoculation prophylaxis, postinoculation prophylaxis, and as therapy on d 5 after inoculation were evaluated in an illness model of RSV infection in BALB/c mice. Pre- and postinoculation prophylaxis reduced $R S V$ replication in lung after primary RSV infection and prevented illness. Day 5 treatment did not affect peak titer of RSV in lung but resulted in more rapid recovery from illness than seen in untreated mice. Prophylaxis prevented antibody responses and lymphocytic infiltrates in lung after primary RSV infection. Treatment caused diminished antibody and pathologic responses. Prophylaxis increased susceptibility to reinfection, although illness after rechallenge was mild. Mice treated therapeutically were less susceptible to reinfection than mice treated prophylactically, but they also experienced mild illness after rechallenge. Passive antibody prophylaxis and treatment of RSV infection are promising approaches to attenuating lower respiratory tract illness from primary RSV infection. The ability to measure illness endpoints and pathology make the BALB/c mouse model of RSV infection a useful system for the preclinical evaluation of immunoprophylactic and immunotherapeutic modalities. (Pediatr Res 34: 167-172, 1993)
\end{abstract}

Abbreviations

Ab, antibody

EMEM, Eagle's minimal essential media

F, fusion glycoprotein in RSV envelope

RSV, respiratory syncytial virus

RSVIG, respiratory syncytial virus immune globulin

RSV is an important cause of respiratory illness in children. Development of preventive or therapeutic approaches is of utmost priority. The level of passively acquired maternal neutralizing $\mathrm{Ab}$ has been shown to be inversely related to the frequency and severity of primary infection in infants (1). The risk of reinfection has also been found to be inversely associated with the level of neutralizing activity in serum (2). The protective effect has been correlated with the amount of serum IgG Ab to

Received January 19, 1993; accepted March 29. 1993.

Correspondence and reprint requests: Barney S. Graham, M.D., Ph.D., A-3310 MCN, Vanderbilt University School of Medicine, Nashville. TN 37232.

Supported in part by NIH Grant NO1-AI-05050. T.D. was supported by the Vanderbilt Minority Access to Research Careers (MARC) Summer Research Program.

${ }^{1}$ Current address: 16921 N.W. 37th Ave., Miami, FL 33056. the fusion glycoprotein of RSV, although the role of Ab-specific for the attachment glycoprotein of the homotypic subtype has not been defined (3). Ab derived from pooled human sera or from RSV-immune cotton rats has been shown to effectively decrease RSV replication in cotton rat lungs when given intraperitoneally either before challenge (4-6) or after challenge with RSV (5). Intraperitoneal administration of pooled human sera before challenge of cotton rats has an additive effect with that of ribavirin on decreasing RSV replication in lung (7). Topical administration of RSV-specific antibody has also effectively decreased replication of RSV in the lungs of cotton rats (20), as has transfer of maternal $\mathrm{Ab}$ in foster feeding experiments $(4,9)$ Treatment of RSV-infected owl monkeys with pooled human sera i.v. has also been shown to diminish RSV replication in lung wash samples (10). RSV-specific MAb preparations have produced similar results in mice (11) and cotton rats (12). All studies have shown that RSV-immune serum preparations whether given parenterally or topically can decrease the replication of RSV in lung, and there has been no evidence of enhanced pathology in any of the model systems. However, RSV-immune $\mathrm{Ab}$ treatment has consistently diminished the $\mathrm{Ab}$ response to RSV challenge $(5,10)$ or vaccination $(13,14)$. RSV-immune Abtreated cotton rats that underwent primary challenge with live RSV were protected from later rechallenge despite low Ab titers (5). However, the diminished $A b$ response to RSV vaccination in cotton rats treated with $\mathrm{RSV}$-immune $\mathrm{Ab}$ resulted in a greater susceptibility to subsequent challenge $(13,14)$.

Studies of RSV immunoprophylaxis and immunotherapy in the cotton rat and owl monkey have been limited by the lack of RSV-induced illness. Nevertheless, because treatment with RSVimmune serum in animal models has shown diminished RSV replication in lung without enhancing lung pathology $(5,10)$, clinical trials of both immunoprophylaxis and immunotherapy have been initiated in children. In an early trial of otherwise healthy infants with RSV lower respiratory tract disease, immunotherapy improved arterial $\mathrm{O}_{2}$ saturations but did not shorten length of hospitalization. There was no evidence of enhanced disease (15). An uncontrolled pilot trial of immunoprophylaxis in high-risk children suggested that although RSV infection was not prevented, illness was mild in most cases (16). Thus, passive immunoprophylaxis and immunotherapy may not only reduce viral shedding, but have the promise of reducing illness. For this study, we have used a reproducible illness model of RSV infection in BALB/c mice (17) to evaluate a specific human immune globulin with high titer of RSV neutralizing Ab (RSVIG) (18) that is currently being evaluated in clinical trials of RSV prophylaxis and treatment. Our experiments will provide the opportunity to validate the observations in the mouse system with those in children when the later data are analyzed. The murine model can potentially be used to anticipate success or problems with 
future products. The key difference between this and previous studies in animal modeis is our ability to measure illness endpoints and demonstrate lung pathology in RSV-infected animals.

\section{MATERIALS AND METHODS}

Mice. Pathogen-free female BALB/c mice were purchased from Charles River Laboratories (Raleigh. NC). Retired breeders ( 8 to 10 mo old) were used in all experiments. They were shipped in filtered crates and housed in a Duo-flo laminar flow unit (Lab Products, Inc., Maywood, NJ) remote from the central animal facility. Cages, bedding, food, and water were sterilized before use. Room temperature was maintained at $27^{\circ} \mathrm{C}$. and a $12-\mathrm{h}-\mathrm{on}$, 12-h-off light cycle was provided. In caring for animals, the investigators adhered to the Guide for the Care and Use of Laboratory Animals, prepared by the Committee on Care and Use of Laboratory Animals of the Institute of Laboratory Animal Resources, National Research Council (National Institutes of Health publication no. 86-23, revised 1985).

$A b$. The Ab used for treatment (RSV Ig, lot no. 3, Massachusetts Public Health Biologic Laboratories, Jamaica Plains, MA) is a human immune globulin prepared from the pooled plasma of donors selected for high neutralizing $A b$ to RSV as previously described (18). After reconstitution from lyophilized powder, RSVIG contains $50 \mathrm{mg}$ of human immune globulin (>95\% IgG) and $10 \mathrm{mg}$ of albumin/mL. RSVIG was administered by intraperitoneal injection of a $200-\mu \mathrm{L}$ suspension.

Cells and virus. Hep-2 cells were maintained in EMEM supplemented with glutamine, amphotericin, gentamicin, penicillin $G$, and $10 \%$ fetal bovine serum (10\% EMEM). The A2 strain of RSV was kindly provided by Dr. Robert Chanock, National Institutes of Health. Working stocks of the virus were prepared as previously described (17) and maintained titers in the range of $10^{8}$ plaque-forming units $/ \mathrm{mL}$ for over $6 \mathrm{mo}$ at $-70^{\circ} \mathrm{C}$.

Mouse infection. Anesthetized mice were infected nasally with $100 \mu \mathrm{L}$ of undiluted stock virus as previously described (17). A clinical illness grading scale was used to assign numbers to a set of clinical features detected in mice with different degrees of illness: 0 , healthy; 1 , barely ruffled fur; 2 , ruffled fur, but active; 3 , ruffled fur and inactive; 4 , ruffled fur, inactive, hunched, and gaunt; and 5, dead. Illness scores were assigned by a blinded observer. Illness was also assessed by weighing the mice and measuring the core body temperature with a vaginal probe (Fisher Scientific, Norcross, GA). Mice were killed, and tissue samples were handled as previously described (17).

Viral quantitation and neutralization tests. Plaque assays for viral quantitation and plaque-reduction neutralization were performed as previously described (17). To determine whether the reduction of RSV titers in lung could be an in vitro effect, a mixing experiment was performed. The supernatants from lungs harvested on $\mathrm{d} 6$ from untreated mice and from mice that had received RSV-immune serum on d 5 were used for the assays. Two hundred $\mu \mathrm{L}$ of cryopreserved lung supernatant from each sample were added to $0.8 \mathrm{~mL}$ of $10 \%$ EMEM, and $200 \mu \mathrm{L}$ of lung supernatant from a treated and untreated mouse were mixed and added to $0.6 \mathrm{~mL}$ of $10 \%$ EMEM for plaque assays.

F ELISA. Immunoaffinity-purified F glycoprotein of RSV and normal Vero cell lysates were a gift from Praxis Biologics, Rochester, NY. F was diluted to $200 \mathrm{ng} / \mathrm{mL}$ in carbonate buffer ( $\mathrm{pH}$ 9.6). One hundred $\mu \mathrm{L}$ of $\mathrm{F}$ suspension were applied to the antigen-positive wells of Immulon II 96-well plates (Nunc, Roskilde, Denmark), and normal Vero cell lysate was applied to the antigen-negative wells in a similar concentration. The performance of the assay has been described previously in detail (19).

\section{RESULTS}

In vitro and in vivo neutralizing activity of $A b$ preparation. The neutralizing titer of the RSVIG Ab preparation was 1:1675 in vitro. Intraperitoneal administration of $200 \mu \mathrm{L}$ to 10 -mo-old
BALB/c mice resulted in a serum neutralization titer of $1: 183$ within $2 \mathrm{~h}$ of administration. Mice were treated with a series of RSVIG dilutions $16 \mathrm{~h}$ before RSV challenge, then killed $72 \mathrm{~h}$ after challenge to measure RSV titer in lung and nose. The titer of RSV recovered from lung and nose was inversely proportional to the amount of $\mathrm{Ab}$ administered and to the resulting serum neutralizing $A b$ titer (Fig. 1). Parenteral administration of RSVIG had a greater effect on the RSV titer in lung than in the nose.

Experimental design. Three time points for RSVIG treatment were chosen relative to the time of RSV challenge. In the d 0 group, mice were treated with $\mathrm{Ab} 2 \mathrm{~h}$ before RSV challenge. The d 1 group received treatment $24 \mathrm{~h}$ after RSV challenge, but before illness was apparent (i.e. during the incubation period). The d 5 group was treated with RSVIG on d 5 when illness is typically first observed in control mice. Mice were killed on d 5 in the $\mathrm{d} 0$ and $\mathrm{d} 1$ treatment groups and on $\mathrm{d} 6$ in the $\mathrm{d} 5$ treatment group to determine the effect of $A b$ treatment on RSV replication in lung and nose. Additional mice were killed on $d 8$ to evaluate the effects on lung pathology. Another set of mice was observed throughout the recovery period after primary infection to evaluate illness parameters and RSV-specific $A b$ responses. This set of mice was rechallenged 1 mo after primary infection to determine their susceptibility to $\mathrm{RSV}$ reinfection. Untreated RSV-infected mice were killed at each time point as controls.

$R S V$ replication after primary infection. Treatment of mice before challenge ( $\mathrm{d} 0$ ), after challenge and before onset of illness (d 1), or at the onset of illness (d 5) was effective in diminishing RSV replication in lung. No virus was isolated from lung in any of the RSVIG-treated mice (Table 1). Nasal RSV replication was also diminished, but not to the same extent. Mixing experiments demonstrated the presence of neutralizing activity in the lung supernatants of $\mathrm{d} 5$-treated mice (Table 2). One d after treatment, there was sufficient $A b$ in lung supernatants from treated mice to diminish the number of plaques by more than 5 -fold in the mixed cultures, presumably by in vitro neutralization or aggregation of RSV in untreated lung supernatants.

Illness and pathology after primary infection. RSV replication was diminished in all RSVIG-treated groups, but only d 0 - and d 1-treated mice remained healthy (clinical score $=0$ ). Even though d 5-treated mice developed the same severity of peak illness as the untreated controls as determined by weight loss, clinical score, and temperature by d 8 after challenge (Table 1), they had an earlier recovery than the untreated control group (Fig. 2). Weight gain in the $\mathrm{d} 5$-treated mice was significantly greater than in the untreated controls at $\mathrm{d} 10(p=0.01)$ and at $\mathrm{d} 11(p=0.02)$. Lung histology in $\mathrm{d} 0-$ and $\mathrm{d} 1$-treated mice

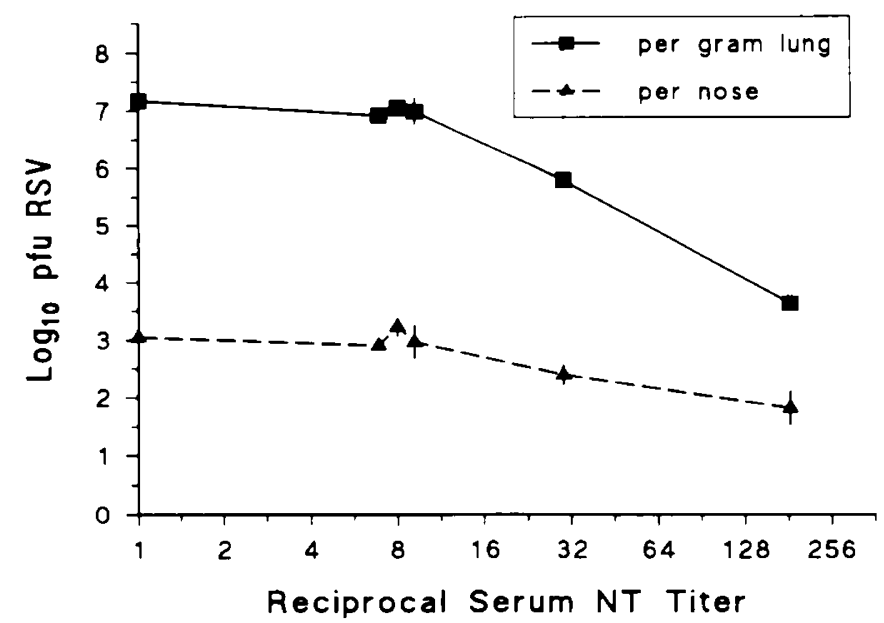

Fig. 1. Relationship of serum-neutralizing $A b$ titer to the quantity of RSV isolated from lung and nose in mice treated prophylactically with RSVIG. Each time point represents the mean values from three mice. 
Table 1. RSI' replication and illness in mice treated prophylactically or therapentically with RSI IG during primary RSI' infection

\begin{tabular}{|c|c|c|c|c|c|c|c|}
\hline \multirow{3}{*}{$\begin{array}{l}\text { Treatment } \\
\text { group }\end{array}$} & \multicolumn{3}{|c|}{ RSV replication* } & & \multicolumn{3}{|c|}{ D 8 illnesst } \\
\hline & & & & Nose & & & Temperature \\
\hline & D 5 & D 6 & D 5 & D 6 & Weight loss & Clinical score & $\left({ }^{\circ} \mathrm{C}\right)$ \\
\hline Do & $<1.8$ & & $1.7 \pm 0.3$ & & $1.2 \pm 0.4$ & & $38.5 \pm 0.2$ \\
\hline D 1 & $<1.8$ & & $1.1(3 / 5) \ddagger$ & & $1.7 \pm 1.0$ & () & $38.2 \pm 0.1$ \\
\hline D 5 & & $<1.8$ & & $1.1(2 / 5)$ & $5.6 \pm 0.5 \$$ & 3.0 & $37.7 \pm 0.3$ \\
\hline None & $6.3 \pm 0.2$ & $5.1 \pm 0.4$ & $2.7 \pm 0.2$ & $2.6 \pm 0.5$ & $5.5 \pm 1.5 \$$ & $2.5 \pm 0.6$ & $37.1 \pm 0.5$ \\
\hline
\end{tabular}

* Values are expressed as geometric means based on $\log _{10}$ plaque-forming units RSV/g lung or $\log _{10}$ plaque-forming units RSV/nose \pm SD.

+ Values are arithmetic means \pm SD. Mice that become ill have reduced temperatures.

$\ddagger$ Number of mice from which RSV was isolated per total in group are recorded in parentheses. Otherwise, values from all five mice evaluated at each time point are included.

$\$$ Compared with the $\mathrm{d} 0$ and 1 treatment groups. $p<0.002$ by two-tailed 1 test.

Table 2. Mixing experiment of lung supernatants from mice killed $6 d$ after primary challenge with RSV to determine the potential for in vitro neutralization

\begin{tabular}{ccccc}
\hline & & \multicolumn{3}{c}{$\begin{array}{c}\text { Mean plaque-forming units/well } \\
\pm \text { SD }^{*}\end{array}$} \\
\cline { 3 - 5 } $\begin{array}{c}\text { Treatment } \\
\text { group }\end{array}$ & Mouse no. & $1: 100$ & $1: 1000$ & $1: 10000$ \\
\hline D 5 & 1 & 0 & 0 & 0 \\
& 2 & 0 & 0 & 0 \\
None & 3 & 0 & 0 & 0 \\
& 4 & TNTC & $105 \pm 7$ & $16 \pm 2$ \\
\multirow{3}{*}{ Mixture } & 5 & $146 \pm 9$ & $86 \pm 5$ & $10 \pm 5$ \\
& 6 & $61 \pm 10$ & $23 \pm 5$ & $3 \pm 1$ \\
& $1+4$ & $15 \pm 5$ & $21 \pm 4$ & $3 \pm 1$ \\
& $2+5$ & $11 \pm 2$ & $12 \pm 2$ & $4 \pm 4$ \\
& $3+6$ & $2 \pm 1$ & $4 \pm 1$ & $1 \pm 1$ \\
\hline
\end{tabular}

* Arithmetic mean of triplicate wells \pm SD for each dilution of supernatant tested in the plaque assay. TNTC. too numerous to count.

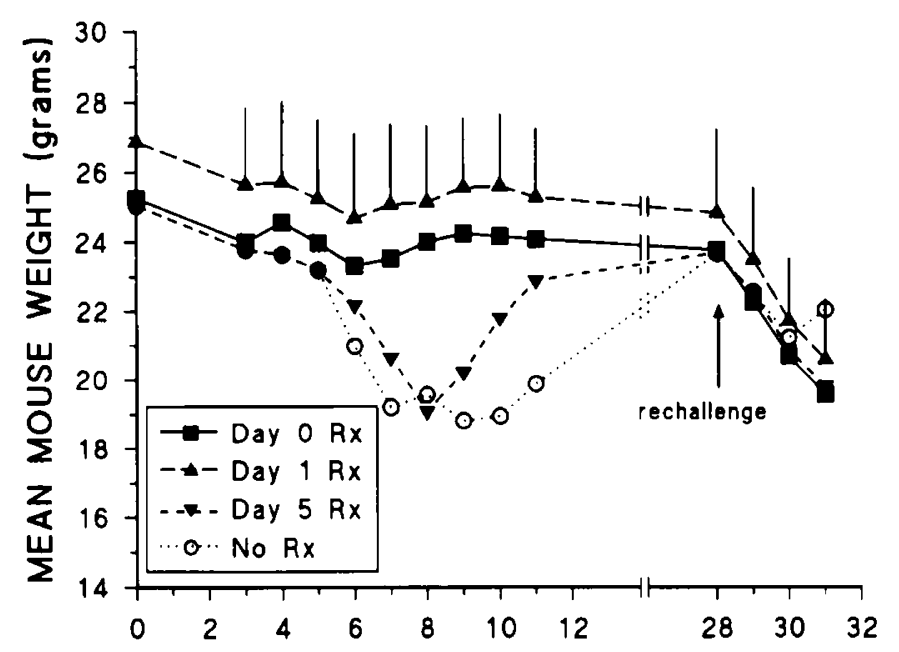

DAYS AFTER PRIMARY RSV CHALLENGE

Fig. 2. Mean weight of mice (five per time point) during primary RSV infection when treated with RSVIG on d 0,1 , or 5 compared with that of untreated mice. Bars represent SD. Mice treated on $d 0$ or 1 had no apparent illness. Mice treated on $\mathrm{d} 5 \mathrm{had}$ a significantly greater weight than untreated mice on $\mathrm{d} 10(p=0.01)$ and $11(p=0.02)$ after inoculation, indicating a more rapid recovery from illness than untreated control mice (two-tailed $t$ test).

was virtually normal, with only small numbers of lymphocytes surrounding the bronchovascular structures. Extensive lymphocyte infiltration around bronchovascular structures and into alveoli observed on $\mathrm{d} 8$ in $\mathrm{d} 5$-treated mice and the untreated controls was indistinguishable (Fig. 3 ).

$A b$ response to primary $R S V$ challenge. Mice treated with RSVIG on $\mathrm{d} 0$ or $\mathrm{d} 1$ did not have a detectable $A b$ response to RSV challenge when tested at d 28. Mice treated at d 5 had a mixed response with most having a low titer or no detectable RSV-specific Ab response, although one mouse in this group had a moderate titer of $\mathrm{Ab}$ to the $\mathrm{F}$ glycoprotein with no detectable neutralization $\mathrm{Ab}$ activity (Fig. 4).

$R S V$ replication after reinfection. Mice from each of the treatment groups were rechallenged on $\mathrm{d} 28$ and killed $3 \mathrm{~d}$ later. There was significant RSV replication in the lungs of mice in the d 0 and $\mathrm{d}$ I RSVIG treatment groups, although less than that seen in primary RSV infection. In the $\mathrm{d} 5$ treatment group, RSV replication in lung was reduced to a greater extent but was still detectable in all mice. There was no RSV detected in the lungs of untreated mice $3 \mathrm{~d}$ after rechallenge. The ability to isolate RSV from the lungs of rechallenged mice was inversely correlated with the $A b$ responses to primary $R S V$ infection. RSV replication in nose after rechallenge was detected at low levels in the $\mathrm{d} 0$ and d 1 treatment groups (Table 3 ). The titer and frequency of RSV isolated from nose after rechallenge in $\mathrm{d} 0$ and $\mathrm{d} 1$ treatment groups, however, was significantly less than that seen in primary infection $(p<0.001$, two-tailed $t$ test). The $\mathrm{d} 5$ treatment group had no RSV isolated from nose after rechallenge.

IIlness and pathology after reinfection. Mice were killed $3 \mathrm{~d}$ after rechallenge, and at that time all treatment groups were continuing to lose weight (Fig. 2). Only the untreated group showed evidence of weight gain by d 3 after rechallenge. Illness based on the clinical score was modest in all treatment groups. but untreated mice appeared healthy (clinical score 0 ) after rechallenge. Therefore, mice treated with RSVIG developed a partial $A b$ response, remained susceptible to RSV reinfection, and experienced mild illness upon rechallenge. In contrast, untreated mice were completely protected from RSV reinfection and had no illness. The lung pathology correlated best with the serum $A b$ response. In mice treated on $d 0$ or $d 1$, there were virtually no lymphocytic aggregates in the peribronchovascular bundles present $3 \mathrm{~d}$ after rechallenge. Untreated mice had typical perivascular and peribronchiolar lymphocytic aggregates (19). The mice treated on $\mathbf{d} 5$ had lymphocytic aggregates in lung after rechallenge, but overall they were smaller than in the untreated controls (Fig. 5).

\section{DISCUSSION}

Major questions regarding the use of passively administered RSV immune serum for the prophylaxis or treatment of RSV infection include: I) Can RSV replication be reduced? 2) Can RSV-induced illness be diminished? 3) Will immune serum cause enhanced illness? and 4) Will treatment blunt the immune response to RSV infection and leave the host more susceptible 

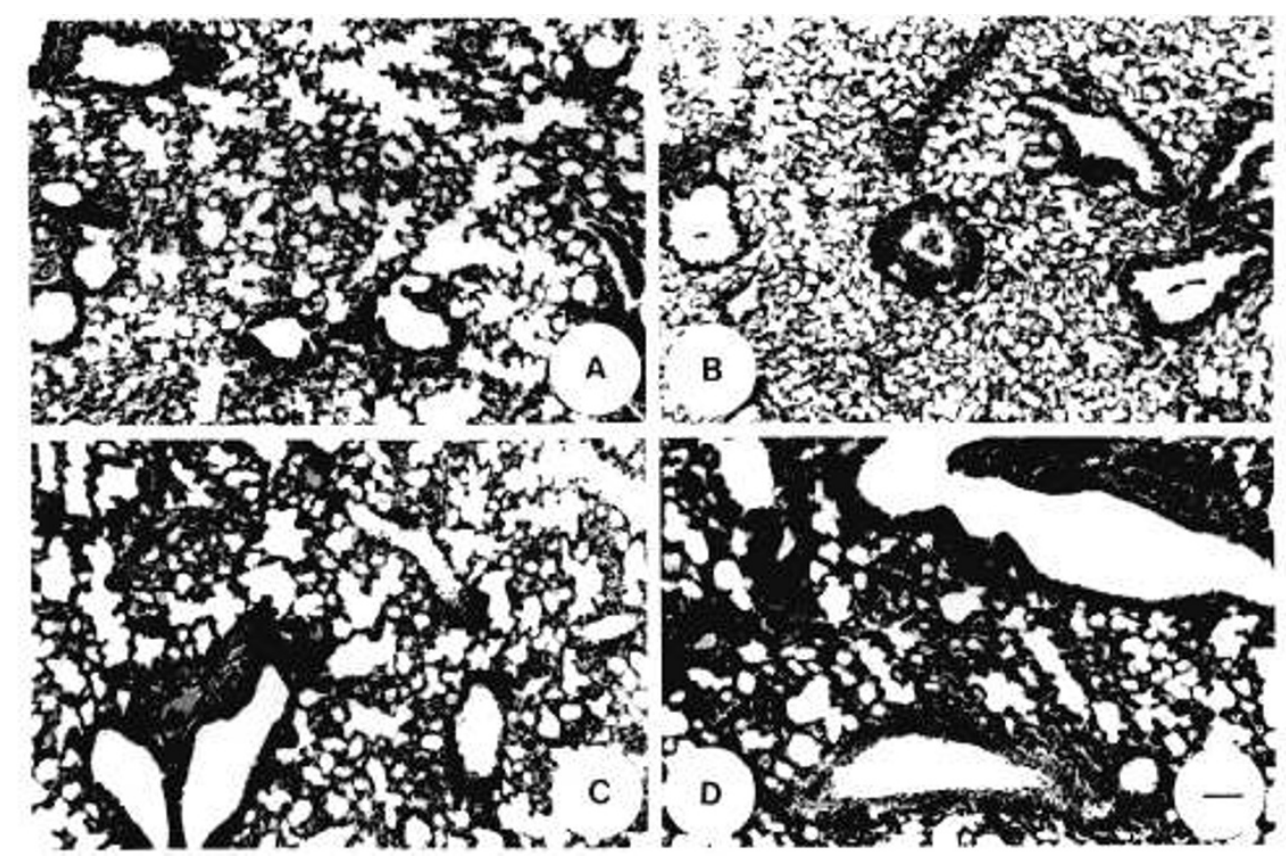

Fig. 3. Photomicrographs of lungs from mice on $\mathrm{d} 8$ after primary infection. Mice were treated with RSVIG on $\mathrm{d} 0$ before inoculation $(A)$, $\mathrm{d} 1$ $(B)$ or $5(C)$ after inoculation, or were untreated $(D)$. Sections were stained with hematoxylin and eosin. Bar $=100 \mu \mathrm{m}$.

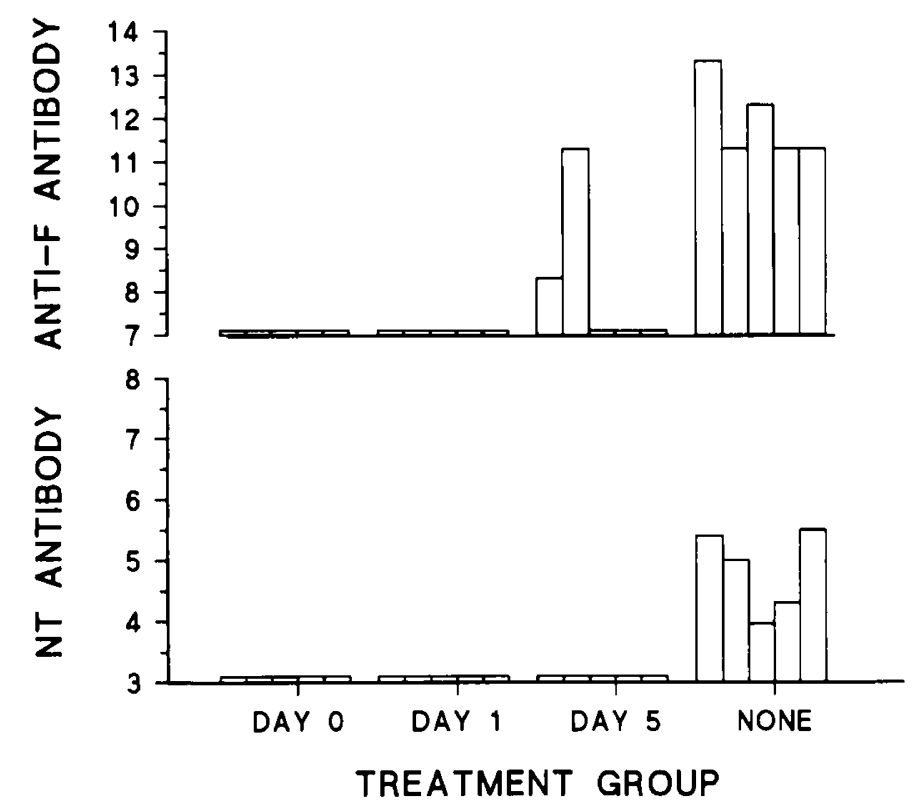

Fig. 4. Ab responses $28 \mathrm{~d}$ after primary RSV infection of individual mice treated on $d 0,1$, or 5 with RSVIG compared with untreated controls. The responses were measured by plaque reduction neutralization and ELISA to $F$, and are recorded as the $\log _{2}$ reciprocal positive serum dilution. The limit of detection in the neutralization assay is 3.3 and in the F ELISA is 7.3.

to severe illness upon reinfection? Previous work in the cotton rat has shown reduced RSV replication after RSV immune serum treatment, but was limited by the lack of illness and pathology in the model system. The current study in a mouse model of RSV infection confirms many of the findings previously made in cotton rats but now adds observations about the role of RSVIG in affecting illness and pathology.

We have demonstrated that passively administered RSVIG effectively diminished the replication of RSV in mice whether used as preexposure prophylaxis, postexposure prophylaxis, or therapy. Limiting RSV replication will decrease direct virusinduced cytopathology, and decreasing viral antigen load should
Table 3. The effect of passive antibody prophylaxis and treatment during primary infection on RSV replication and illness on 3 after rechallenge of mice with $R S V$

\begin{tabular}{|c|c|c|c|c|c|}
\hline \multirow{3}{*}{$\begin{array}{l}\text { Treatment } \\
\text { group }\end{array}$} & \multirow{2}{*}{\multicolumn{2}{|c|}{$\begin{array}{l}\text { RSV replication* after } \\
\text { rechallenge }\end{array}$}} & \multicolumn{3}{|c|}{ D 3 illnesst after rechallenge } \\
\hline & & & \multirow{2}{*}{$\begin{array}{l}\text { Weight } \\
\text { loss }\end{array}$} & \multirow{2}{*}{$\begin{array}{l}\text { Clinical } \\
\text { score }\end{array}$} & \multirow{2}{*}{$\begin{array}{c}\text { Temperatur } \\
\left({ }^{\circ} \mathrm{C}\right)\end{array}$} \\
\hline & Lur & No & & & \\
\hline D & & & & & \\
\hline D & & , & & & \\
\hline D & \pm & & & 2. & \\
\hline None & $<1.8$ & $1.1(1 / 5)$ & 1.7 & 0 & 37.6 \\
\hline
\end{tabular}

*Values are expressed as geometric means based on $\log _{10}$ plaqueforming units $\mathrm{RSV} / \mathrm{g}$ lung or $\log _{10}$ plaque-forming units $\mathrm{RSV} /$ nose \pm SD.

+ Values are arithmetic means \pm SD.

$\ddagger$ Number of mice from which RSV was isolated per total in group are recorded in parentheses. Otherwise, values from all five mice evaluated at each time point are included.

$\$$ Compared with day 0 or 1 treatment groups. $p<0.001$

$\|$ Compared with $\mathrm{d} 0$ or 1 treatment groups. $p<0.001$ : compared with d 5 treatment group. $p<0.02$, by two-tailed $t$ test.

decrease the strength of the immune response, which is also a factor in the severity of illness $(20,21)$.

The potential for in vitro neutralization of RSV by passive $A b$ in the lungs of RSV-immune serum-treated mice has not been noted in previous work examining passive $A b$ treatment of RSV in cotton rats $(5-8)$. One factor may be that RSVIG has $\sim 5$-fold higher neutralizing activity than standard i.v. immune globulin preparations used previously. In vitro neutralization of RSV in these mixing experiments indicates the presence of residual antiRSV activity in the lungs of treated mice and emphasizes the importance of illness endpoints in discriminating RSVIG effects in vivo. Decreased RSV in the lungs of mice treated with RSVIG on $\mathrm{d} 0$ and $\mathrm{d} 1$ closely paralleled reductions in RSV illness and pathology. We therefore believe that decreased virus recovery from RSV challenged animals reflects neutralization of virus before killing.

When treatment was initiated before the onset of illness, the severity of illness, $\mathrm{Ab}$ response, and lung pathology from primary 


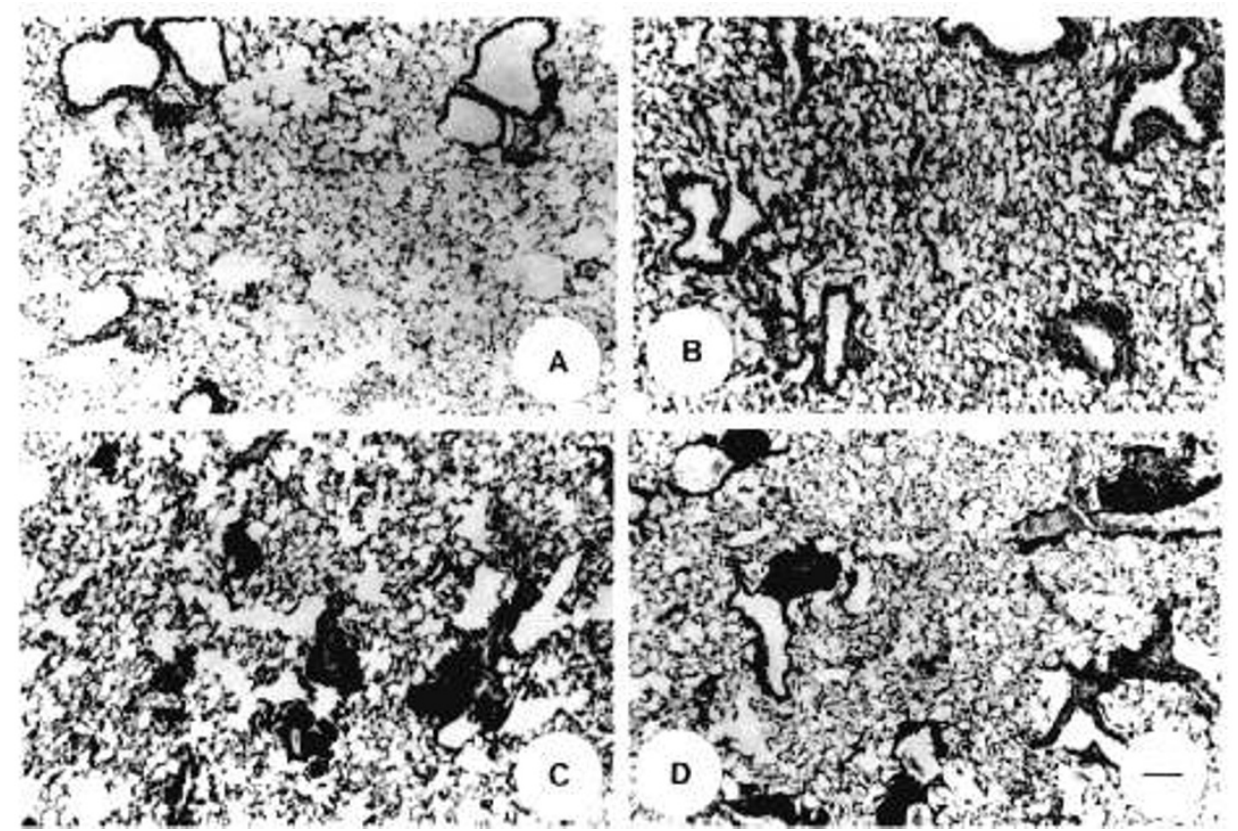

Fig. 5. Photomicrographs of lungs from mice on $\mathrm{d} 3$ after rechallenge. At the time of primary infection, mice were treated with RSVIG on $\mathrm{d} 0$ before inoculation $(A), \mathrm{d} 1(B)$ or $5(C)$ after inoculation, or were untreated $(D)$. Sections were stained with hematoxylin and eosin. $B a r=100 \mu \mathrm{m}$.

RSV infection was markedly diminished. Serologic studies in infants $(1,2)$ and the reports of diminished pathology and decreased illness in colostrum-fed bovine RSV-infected calves (22) anticipated these results. If treatment was initiated at the first sign of illness (d 5), the maximal severity of illness was unchanged, but the duration of illness was shortened. Our observations have important implications for use of RSV-immune serum preparations in human subjects. Clearly, our results would predict that RSVIG administered prophylactically would offer the greatest protection against RSV lower respiratory tract illness. Nevertheless, even mice treated with RSVIG on d 5, a time of peak virus replication in lung, recovered more quickly than untreated mice. If the dynamics of pulmonary virus replication and immune response in mice and man are comparable, treatment with RSVIG after onset of pulmonary disease may therefore provide benefit. In the only pediatric trial reported to date, a standard human i.v. immune globulin, selected for relatively high neutralizing activity against RSV, had a modest impact on the overall severity of RSV-induced illness if begun after the onset of lower respiratory tract symptoms (15). The mechanism by which RSVIG shortens duration of illness is not known. The decrease in RSV antigen might reduce activation of the immune system and thereby reduce the amount of immunopathology. Alternatively, $\mathrm{Ab}$ might directly modify the immune response and decrease immune-mediated disease. There is evidence in mice that passively acquired $\mathrm{Ab}$ can diminish the cytotoxic $\mathrm{T}$ cell response to RSV (23).

There are potential differences in the action of human Ig in mice as compared with man because of altered $\mathrm{Fc}$ affinity for cells mediating antibody-dependent cell-mediated cytotoxicity or phagocytosis. Complement binding and activation may also be different than with species-specific Ig. There may also be a difference in the way cellular responses are modified in the presence of a nonmurine Ig. However, human instead of mouse Ig should not make a difference in direct neutralization of RSV, which is the dominant mechanism of $\mathrm{Ig}$ action in the cotton rat model of RSV (24). Treatment of cotton rats with Fab fragments or treatment of complement-depleted cotton rats had no effect on protective efficacy (24).

RSVIG treatment resulted in diminished RSV-specific Ab responses to primary RSV infection in the mice, and this correlated directly with the susceptibility to reinfection of lung upon rechallenge with RSV. Susceptibility to reinfection of lung after rechallenge in the setting of low or absent RSV-specific Ab has been previously demonstrated in mice $(18,25)$. Diminished $\mathrm{Ab}$ response to RSV antigens in the presence of passively acquired $\mathrm{Ab}$ has been demonstrated in several systems $(5,10,13,14)$, but in owl monkeys (10) and cotton rats (5) this did not effect susceptibility to reinfection as it did in our system. This may relate to differences in amount of RSV in the challenge inocula, the potency of the RSV immune sera used for treatment, or features of the experimental design or model system. Whereas RSVIG treatment increased the susceptibility of lung to reinfection, replication of RSV in nose after rechallenge was attenuated even in the RSVIG-treated mice (Table 3). In man. lung inoculation with RSV is probably the consequence of aspirating RSVladen nasal secretions. In contrast, the mouse model requires direct inoculation of lung to achieve lower respiratory tract infection. Evidence of nasal immunity to reinfection despite RSVIG treatment may therefore indicate that man might be less susceptible to subsequent lower respiratory tract infection after RSVIG treatment than predicted by the mouse model.

RSVIG treatment decreased the lymphocytic infiltrate after rechallenge. Decreased size of the lymphocytic infiltrates and reduced serum $\mathrm{Ab}$ response were correlated with increased susceptibility to lung reinfection. The correlation of protection from lung reinfection with the presence of lymphocytic aggregates in lung and presence of RSV-specific serum Ab has also been seen in previous studies $(19,21)$. Even though illness after rechallenge was more apparent in RSVIG-treated mice, the illness compared with primary infestion was attenuated. Because most severe illness is typically seen in infants infected with RSV in the first year of life, susceptibility to reinfection may not prove critical in guiding strategies of intervention. Rather, the ability of an RSVimmune serum preparation to delay RSV infection beyond the first year of life may significantly reduce morbidity.

In summary, we have evaluated a human RSVIG preparation in mice that is being concurrently tested in infants for immunoprophylaxis and immunotherapy. The human trial will ultimately allow direct evaluation of the model's validity for predicting the outcome of future clinical trials. The current study has shown that preexposure prophylaxis and immediate postexposure prophylaxis of RSV-infected mice reduces RSV replication in lung and illness during primary infection but decreases the RSV-specific Ab response. This results in susceptibility to reinfection of lung associated with mild illness. Immunotherapy 
of RSV-infected mice at the time illness is first apparent results in earlier recovery from illness even though peak RSV titers in lung and maximal illness are no different than in untreated controls. These data support continued evaluation of the use of RSVIG in clinical trials and exploration of new Ab formulations and methods for delivery in this mouse model of RSV infection.

Acknowledgments. The authors thank Dr. Gregory Prince and Dr. George Siber for reviewing the manuscript, Mentoria Jennings for assistance in preparing the manuscript, and MedImmune, Inc. (Gaithersburg, MD) for supplying the RSVIG.

\section{REFERENCES}

1. Glezen WP, Paredes A, Allison JE, Taber LH, Frank AL 1981 Risk of respiratory syncytial virus infection for infants from low-income families in relationship to age, sex, ethnic group, and maternal antibody level. J Pediatr 98:708-715

2. Glezen WP, Taber LH, Frank AL. Kasel JA 1986 Risk of primary infection and reinfection with respiratory syncytial virus. Am J Dis Child 140:543546

3. Kasel JA, Walsh EE, Frank AL, Baxter BD, Taber LH, Glezen WP 1987 Relation of serum antibody to glycoproteins of respiratory syncytial virus with immunity to infection in children. Viral Immunol 1:199-205

4. Prince GA, Horswood RL, Camargo E, Koenig D, Chanock RM 1983 Mechanisms of immunity to respiratory syncytial virus in cotton rats. Infect Immun 42:81-87

5. Prince GA, Hemming VG, Horswood RL, Chanock RM 1985 Immunoprophylaxis and immunotherapy of respiratory syncytial virus infection in the cotton rat. Virus Res 3:193-206

6. Prince GA, Horswood RL, Chanock RM 1985 Quantitative aspects of passive immunity to respiratory syncytial virus infection in infant cotton rats. J Virol 55:517-520

7. Gruber WC, Wilson SZ, Throop BJ, Wyde PR 1987 Immunoglobulin administration and ribavirin therapy: efficacy in respiratory syncytial virus infection in the cotton rat. Pediatr Res 21:270-274

8. Prince GA, Hemming VG, Horswood RL, Baron PA, Chanock RM 1987 Effectiveness of topically administered neutralizing antibodies in experimental immunotherapy of respiratory syncytial virus infection in cotton rats. J Virol 61:1851-1854

9. Wong DT, Ogra PL 1986 Neonatal respiratory syncytial virus infection: role of transplacentally and breast milk-acquired antibodies. J Virol 57:12031206

10. Hemming VG, Prince GA, Horswood RL, London WT, Murphy BR, Walsh EE, Fischer GW, Weisman LE, Baron PA. Chanock RM 1985 Studies of passive immunotherapy for infections of respiratory syncytial virus in the respiratory tract of a primate model. J Infect Dis 152:1083-1087
11. Taylor G, Stott EJ, Bew M, Fernie BF, Cote PJ, Collins AP, Hughes M, Jebbert J 1984 Monoclonal antibodies protect against respiratory syncytial virus infection in mice. Immunology 52:137-141

12. Walsh EE, Schlesinger JJ, Brandriss MW 1984 Protection from respiratory syncytial virus infection in cotton rats by passive transfer of monoclonal antibodies. Infect Immun 43:756-758

13. Murphy BR, Olmsted RA, Collins PL, Chanock RM, Prince GA 1988 Passive transfer of respiratory syncytial virus (RSV) antiserum suppresses the immune response to the RSV fusion (F) and large $(G)$ glycoproteins expressed by recombinant vaccinia viruses. J Virol 62:3907-3910

14. Murphy BR, Prince GA, Collins PL, Hildreth SW, Paradiso PR 1991 Effect of passive antibody on the immune response of cotton rats to purified $F$ and $G$ glycoproteins of respiratory syncytial virus (RSV). Vaccine 9:185-189

15. Hemming VG, Rodriguez W, Kim HW. Brandt CD, Parrott RH, Burch B Prince GA, Baron PA, Fink RJ, Reaman G 1987 Intravenous immunoglobulin treatment of respiratory syncytial virus infections in infants and young children. Antimicrob Agents Chemother 31:1882-1886

16. Groothuis JR, Levin MJ, Rodriguez W, Hall CB, Long CE, Kim HW, Lauer BA, Hemming VG, RSVIG Study Group 1991 Use of intravenous gamma globulin to passively immunize high-risk children against respiratory syncytial virus: safety and pharmacokinetics. Antimicrob Agents Chemother 35:1469-1473

17. Graham BS, Perkins MD, Wright PF, Karzon DT 1988 Primary respiratory syncytial virus infection in mice. J Med Virol 26:153-162

18. Siber GR, Leszczynski J, Pena-Cruz V. Ferren-Gardner C, Anderson R, Hemming VG, Walsh EE, Burns J, Mclntosh K, Gonin R, Anderson LJ 1992 Protective activity of a human respiratory syncytial virus immune globulin prepared from donors screened by microneutralization assay. J Infect Dis 165:456-463

19. Graham BS, Bunton LA, Wright PF, Karzon DT 1991 Reinfection of mice with respiratory syncytial virus. J Med Virol 34:7-13

20. Cannon MJ, Openshaw PJM, Askonas BA 1988 Cytotoxic T cells clear virus but augment lung pathology in mice infected with respiratory syncytial virus. J Exper Med 168:1163-1168

21. Graham BS, Bunton LA, Wright PF, Karzon DT 1991 The role of T cell subsets in the pathogenesis of primary infection and reinfection with respiratory syncytial virus in mice. J Clin Invest 88:1026-1033

22. Belknap EB, JC Baker JC, Patterson JS, Walker RD, Haines DM, Clark EG 1991 The role of passive immunity in bovine respiratory syncytial virusinfected calves. J Infect Dis 163:470-476

23. Bangham CRM 1986 Passively acquired antibodies to respiratory syncytia virus impair the secondary cytotoxic T-cell response in the neonatal mouse Immunology 59:37-42

24. Prince GA. Hemming VG. Horswood RL. Baron PA. Murphy BR. Chanock RM 1990 Mechanism of antibody-mediated viral clearance in immunotherapy of respiratory syncytial virus infection of cotton rats. J Virol 64 3091-3092

25. Graham BS, Bunton LA, Wright PF, Karzon DT 1991 Respiratory syncytial virus in anti- $\mu$ treated mice. $J$ Virol 65:4936-4942 